\title{
Risk factors for papillary thyroid cancer in obesity and diabetes mellitus
}

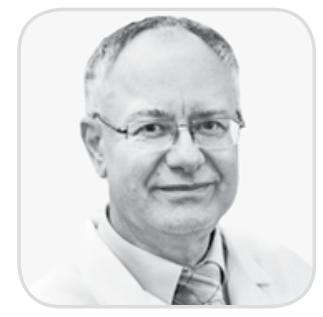

S. G. Gychka ${ }^{1}$, B. Ya. Serbin ${ }^{1}$, S. I. Nikolaenko ${ }^{1}$, M. A. Matviian 1, S. Sujima ${ }^{2}$, O. A. Tovkai ${ }^{3}$

${ }^{1}$ Bogomolets National Medical University, Kyiv

${ }^{2}$ Kyiv Medical University

${ }^{3}$ Ukrainian Scientific and Practical Center for Endocrine Surgery, Transplantation of Endocrine Organs and Tissues of the Ministry of Health of Ukraine, Kyiv
Overweight and obesity, collectively referred to as «overweight», are defined as abnormal or excessive fat accumulation that causes many chronic diseases and shortens life expectancy [1]. The prevalence of overweight is increasing worldwide. Thus, in 2016, approximately $40 \%$ of adults and $18 \%$ of children (aged 5-19 years) were overweight, amounting to almost 2 billion adults and 340 million children [4]. In 2015, an estimated 4 million deaths were due to overweight [2]. The economic impact of diseases related to overweight is extremely unprofitable as the estimation was around 2.0 trillion USD in 2014 [3]. Except for a few economically independent or highincome countries, others have seen an increase in the prevalence of overweight in recent years among all populations [4]. The fastest growth is observed in lowand middle-income countries, probably due to the introduction of a «Western lifestyle», which consists of a high-calorie diet, nutrient-poor foods, and reduced physical activity [5]. Since obesity is often related to diabetes mellitus (DM) and violation of the microbiota of the intestine, our study aims to summarize the evidence of the impact of these risk factors on the possible development of papillary thyroid cancer.

\section{Adiposity}

Being overweight is associated with the risk of developing various cancers $[6,7]$. Although the impact of overweight, as a risk of developing on cancer is moderate as compared to other triggers, the development and implementation of a consumer model of behavior in all countries of the world will lead to a significant increase in these figures.

Various mechanisms have been proposed until now to explain how being overweight affects cancer risk. The main ones are changes in the hormonal system (peptide metabolism hormones, sex steroid hormones) and chronic inflammation, which are the most studied hypotheses.

Increased body mass index will increase the number of adipocytes that secrete adipokines that will continue to stimulate mitogenic cell division [12]. A meta-analysis shows that increasing the body mass index by $5 \mathrm{~kg} / \mathrm{m} 2$ increases the risk of thyroid cancer in men $(R R=1.33 ; P=0.02)$ and women $(R R=1.14 ; P$ $=0.001$ ) [13]. Scientists explain this by the effect of adipokines such as leptin, adiponectin, and hepatocyte growth factor on follicular cell proliferation, which provokes the growth of cancer cells. Adiponectin is the most studied adipokine in terms of cancer risk [14, 15]. Serum adiponectin levels are negatively correlated with BMI through several mediators (e.g., insulin, tumor necrosis factor $a$, estrogen), which inhibit transcription. The influence on the development of the tumor occurs by sensitization of the cells to

Гичка Сергій Григорович, д. мед. н., проф., зав. кафедри патологічної анатомії № 2. E-mail: s.gychka@nmu.ua. ORCID:http://orcid.org/0000-0002-6821-0085; Сербін Богдан Ярославович, лікар-інтерн кафедри оториноларингології; Ніколаєнко Софія Ігорівна, ст. лаборант кафедри патологічної анатомії № 2. ORCID: http://orcid.org/0000-0002-0655-5344; Матвіян Марія Анатоліївна, ст. лаборант кафедри патологічної анатомії №2; С. Суджіма, студентка ПВНЗ «Київський медичний університет»; Товкай Олександр Андрійович, д. мед. н., директор УНПцЕХ, старший науковий співробітник відділу ендокринної хірургії УНПЦЕХ. 01021, м. Київ, вул. Кловський узві3, 13-A. ORCID:http://orcid.org/0000-0002-1329-279X. E-mail: director.tovkai@gmail.com. 
insulin or through anti-inflammatory action. Adiponectin can also have an anti-tumor effect directly by regulating the metabolic, inflammatory, and signaling pathways of the cell cycle [16]. These experimental studies strongly confirm the role of adiponectin in different types of cancer, including breast cancer, kidney, liver, pancreas, thyroid cancer, myeloma, stomach, esophagus, prostate and colorectal cancer [17]. However, observational studies on the relationship between the diagnostic level of adiponectin and the risk of several cancers have reported mixed results [18-22].

Adipose tissue, as an endocrine organ, affects the synthesis and bioavailability of sex hormones. Adipose tissue produces aromatase enzymes that convert androgens to estrogens and convert less active forms of these hormones (androstenedione, estrone) into more active forms (testosterone, estradiol) and increase the concentration of sex hormone-binding globulin in the blood that cause increasing the bioavailability of free estradiol and testosterone. It is believed that the sex steroid hormones appear mediators due to the risk of breast and endometrial cancer and possibly increases the risk of prostate and colon cancer [23]. In postmenopausal obese women, the rate of conversion of androgens to estrogens is increased [24]. In an analysis with a combination of 8 prospective studies, the association of BMI with postmenopausal breast cancer risk was almost entirely explained by an increase in estradiol levels with an increase in BMI [25]. In men, etiologic role that links hormones with advanced prostate cancer is not fully understood [26]. In obese people, there is an increase in serum estradiol levels and a decrease in androgen levels [27]. Because androgens play an important role in the normal growth and differentiation of prostate epithelial cells, one hypothesis is that a reduction in bioavailable testosterone, in particular, may contribute to more advanced prostate cancer [28]. Indeed, at least 2 prospective studies have shown that a lower level of diagnosis of circulating androgens has been associated with a risk of high-quality, poorly differentiated prostate cancer [29,30].

Adipose tissue produces and secretes a wide range of pro-inflammatory molecules, including tumor necrosis factor a and interleukin-6, which can cause local inflammation of adipose tissue and systemic effects on other organs $[16,29]$. Complete chronic inflammation, often found in obese people, predisposes to a particular type of cancer, creating a tissue environment that creates oxidative stress, stimulates DNA damage, increases cell proliferation, and inhibits apoptosis. Several examples of local inflammation related to the risk of cancer include the association of the non-alcoholic fatty liver disease with liver cancer $[29,31]$ chronic acid reflux, the development of Barrett's esophagus, and esophageal adenocarcinoma [32, 33], and the association of chronic gallstones disease and cholecystitis with gallbladder cancer [34, 35].

Also, fat significantly increases insulin resistance, which significantly increases the chances of carcinogenesis (see below).

\section{Diabetes mellitus}

Despite the tremendous development of medicine and the improvement of the quality and life expectancy of people, the incidences of diabetes mellitus (DM) is only increasing. According to WHO's statistics, there were 422 million cases of DM (in adults) in the world in 2014, which is four times more than in 1980 [32]. A significant role in the growth of this indicator is the increase in the incidence of type 2 DM, which is directly related to the rise in factors as overweight and obesity [2].

It is a well-known fact that diabetes is the main trigger in the development of pathological conditions such as macroangiopathy (damage to the coronary vessels of the heart, brain, and vessels of the legs) and microangiopathy (damage to small vessels of the retina, kidneys, legs) [3]. In addition to these complications, DM is also one of the driving factors in the development of cancer, namely, colon cancer, pancreatic cancer, breast cancer, bladder cancer, prostate cancer, and non-Hodgkin's lymphoma [33].

However, does DM have an effect on the development of thyroid cancer since? Because this type of tumor is much more often diagnosed now, we must not forget about the rapid tendency to malignancy and high mortality caused by this pathology [5]. According to epidemiological statistics [6], only ionizing radiation can be directly related to the development of the disease, and benign tumors and abuse or inadequate intake of iodine are a risk factor. However, none of these reasons explains the incline in the thyroid cancer cases. Epidemiological studies [7] show that the occurrence of thyroid cancer pathology in people with DM (10.8\%) are more frequent than in the general population $(6.6 \%)$, therefore, in this article, we will try to find a connection 
between the nosology by analyzing the research of our foreign colleagues.

To begin with, it is necessary to establish a causal relationship between these pathologies at the pathophysiological level, as DM can cause the development of the neoplastic process of the thyroid gland [34]. DM can affect the mitotic division of follicular cell through several mechanisms. Increased insulin stimulates follicular cells to divide due to structural similarity to insulin-like growth factors [35]. Studies show that when culturing follicular cells, their quantity increases significantly in the presence of insulin and TSH as compared to the presence of only TSH [36]. This is evidence of the phenomenon of insulin mimicry to insulin-like factor 1 which is due to the effect on cell growth receptors. From this, we can conclude that in vivo increased amount of insulin will lead to hyperplasia of the follicular epithelium, which is a prerequisite for carcinogenesis and for a much faster progression of cancer [11].

The anti-diabetic drugs sulfonylurea and injectable insulins increases the concentration of the insulin in the blood [14, 15], which as mentioned above, stimulates receptor for the activation and promotion of cell growth, and proliferation of follicle. Studies show that the risk of cancer increases by $20 \%$ with each year of insulin therapy [16].

Hyperglycemia and hypertriglyceridemia increase oxidative stress [17] by activating nuclear factor «k-B». This factor activates the production of nitric oxide, which is a substance for the formation of reactive oxygen species. These types of small quantities of oxygen are involved in the signaling and proliferative processes of the cell, whereas, in large quantities they are found in cancer cells [18]. However, a significant study in 2011 with a large cohort of subjects shows that women with elevated blood glucose do not affect the development of thyroid cancer, but men, on the contrary - increases the risk of oncology [19]. At the moment, it is impossible to say unequivocally about this thesis, because the interaction of glucose, thyroid hormones, and sex hormones is complex and not fully known.

For unknown reasons, DM causes a deficiency of vitamin $D$, which leads to a decrease in iodothyronine deiodinase 2, which, in turn, reduces the level of triiodothyronine in the intracellular space. Low levels of triiodothyronine in soft tissues help reduce GLUT-4, a glucose transporter that causes insulin resistance. In turn, low levels of T3 cause the production of TSH, which is already in excess due to DM [20].

Thus, as a result, there is an excess of glucose, TSH, insulin, triglycerides, adipokines that activate uncontrolled division of follicular cells, which is a prerequisite for the neoplastic process [21] in theory. However, to confirm this theory, it requires metaanalyzes and cohort studies of actual patients who prove, or disprove the link between DM and thyroid cancer.

According to several studies $[6,8,22-24]$, the link between DM and thyroid cancer is weak in women, but for men with DM, the connection is even weaker or not observed at all. The results are controversial and ambiguous, so it is impossible to claim that DM is one of the risk factors for thyroid cancer at this stage.

However, in the process of the study, a connection between DM and the rate of progression of cancer was established [25], namely the growth and invasion of the primary tumor through the influence of insulin on insulin-like growth factor receptors. Therefore, we can say that this effect is not DM itself, but drugs for its treatment, drugs that raise the natural level of insulin or injectable insulin drugs themselves [26].

Proof of this is the number of studies that demonstrate a significantly lower incidence of cancer and remission in cancer patients with type 2 DM treated with metformin [27, 28] and acarbose [25] compared to other comorbid patients treated with insulin replacement therapy and its synthetic analogues.

The Fig. 1 illustrates pathologic mechanisms underlying the increase in the risk of the development of thyroid cancer.

Also, the research to indicate a positive effect of metformin in the treatment of papillary cancer of the thyroid caused by overweight is very interesting [29]. Metformin reduces the development, invasion, and metastasis of this type of cancer by blocking leptin receptors [30], and to some extent, prevents the occurrence of papillary thyroid cancer induced by obesity [31].

\section{Microbiota}

Summarizing all the above risk factors for cancer, we must mention the intestinal microbiota, the violation of which leads to both obesity and DM. The role of commensal microorganisms is often underestimated, but they are indispensable in the development and functioning of the immune system [58]. For example, cells of microbiota feeds on signals required for the normal development of lymphoid her tissue associated 
Overview of results of prospective cohort studies and meta-analyzes of communication in between diabetes mellitus and thyroid cancer

\begin{tabular}{|c|c|c|c|c|c|c|}
\hline № & $\begin{array}{l}\text { Year and author } \\
\text { of a study }\end{array}$ & Country & $\begin{array}{l}\text { Name } \\
\text { of investigations }\end{array}$ & Form of research & $\begin{array}{l}\text { Number of cases/years } \\
\text { of research }\end{array}$ & Risk ratio \\
\hline $1[6]$ & $\begin{array}{l}2010 \\
\text { C.L. Meinhold } \\
\text { et al. }\end{array}$ & USA & $\begin{array}{l}\text { The US } \\
\text { Radiologic } \\
\text { Technologists } \\
\text { Study }\end{array}$ & $\begin{array}{l}\text { special cohort } \\
\text { study }\end{array}$ & $\begin{array}{l}69,506 \text { women, } 21,207 \\
\text { men from } 1983 \text { to } 2006\end{array}$ & $\begin{array}{l}\text { women : HR = } 1.37 \\
(95 \% \mathrm{Cl}: 0.49-3.77) \\
\text { forehead Ages: NA }\end{array}$ \\
\hline $2[8]$ & $\begin{array}{l}2011 \mathrm{~B} . \\
\text { Aschebrook- } \\
\text { Kilfoy } \\
\text { et al. }\end{array}$ & USA & $\begin{array}{l}\text { The NIH-AARP } \\
\text { Diet and Health } \\
\text { Study }\end{array}$ & $\begin{array}{l}\text { prospective cohort } \\
\text { study }\end{array}$ & $\begin{array}{l}\text { 200,556 women, } \\
\text { 295,992 men Average } \\
\text { study time: } 10 \text { years }\end{array}$ & $\begin{array}{l}\text { women: } \mathrm{HR}=1.54 \\
(95 \% \mathrm{Cl}: 1.08-2.20) \\
\text { men: } \mathrm{HR}=1.11(95 \% \\
\mathrm{Cl}: 0.74-1.66)\end{array}$ \\
\hline $3[22]$ & $\begin{array}{l}2012 \\
\text { C.M. Kitahara } \\
\text { et al. }\end{array}$ & USA & $\begin{array}{l}\text { Physical } \\
\text { activity, } \\
\text { diabetes, and } \\
\text { thyroid cancer } \\
\text { risk: a pooled } \\
\text { analysis of five } \\
\text { prospective } \\
\text { studies }\end{array}$ & $\begin{array}{l}\text { Combined analysis } \\
\text { of five prospective } \\
\text { studies, including } \\
\text { diet and health } \\
\text { research NIHAARP } \\
\text { (NIH-AARP), } \\
\text { Prostate, Lung } \\
\text { Cancer, Colorectal } \\
\text { Cancer and } \\
\text { Ovarian Cancer } \\
\text { Screening Study } \\
\text { (PLCO), Breast } \\
\text { Cancer Detection } \\
\text { and Demonstration } \\
\text { Project), } \\
\text { Agricultural Health } \\
\text { Research (AHS) and } \\
\text { US Radiological } \\
\text { Technology } \\
\text { Research (USRT) }\end{array}$ & $\begin{array}{l}312,149 \text { women, } \\
\text { 362,342 men Average } \\
\text { study time: } 10.5 \text { years }\end{array}$ & $\begin{array}{l}\text { women: } \mathrm{HR}=1.19 \\
\text { (95 \% Cl: } 0.84-1.69) \\
\text { men: } \mathrm{HR}=0.96(95 \% \\
\mathrm{Cl}: 0.65-1.42)\end{array}$ \\
\hline 4 [23] & $\begin{array}{l}2014 \\
\text { Yohwan Yeo et al. }\end{array}$ & Korea & $\begin{array}{l}\text { Diabetes } \\
\text { Mellitus and } \\
\text { Risk of Thyroid } \\
\text { Cancer: A Meta- } \\
\text { Analysis }\end{array}$ & Purpose - analysis & $\begin{array}{l}19 \text { cohort studies were } \\
\text { analyzed, the results of } \\
\text { which were published in } \\
\text { 1992-2012 }\end{array}$ & $\begin{array}{l}\text { Women }(\mathrm{RR}=1.384 \\
95 \% \mathrm{Cl} 1.13-1.67) \\
\text { Men }(\mathrm{RR}=1.11,95 \% \\
\mathrm{Cl} 0.80-1.53) .\end{array}$ \\
\hline $5[24]$ & $\begin{array}{l}2016 \\
\text { Juhua Luo et al. }\end{array}$ & USA & $\begin{array}{l}\text { Diabetes, } \\
\text { Diabetes } \\
\text { Treatment, and } \\
\text { Risk of Thyroid } \\
\text { Cancer }\end{array}$ & $\begin{array}{l}\text { prospective cohort } \\
\text { study }\end{array}$ & $\begin{array}{l}147934 \text { women for } 16 \\
\text { years of observation }\end{array}$ & $\begin{array}{l}\text { hazard ratio = 1.09; } \\
95 \% \text { confidence } \\
\text { interval, } 0.79-1.52\end{array}$ \\
\hline
\end{tabular}

with the intestine (GALT), capture IgA-producing plasma cells, and activation of T-lymphocytes, which proceeded after birth at mammals [59]. In vertebrates animals, many products of the commensal microbiota and pathogens, which act in part on innate receptors of the TLR and NOD-like receptors, affect barrier immunity through pro- and anti-inflammatory mechanisms. The role of TLR and the IL-1 receptor family in the control of intestinal microbiology is demonstrated in mice with deficiency in MyD88 adapter molecules, in which microbial-regulated genes have altered expression [60]. MyD88 - molecules required for epithelial expression of antimicrobial genes such as Reg3 $\beta$ and Reg3y, and MYD88 deficiency leads to changes in the composition of bacterial microbiota $[60,61]$. It is important to remember that, in addition to bacteria, the microbiota has archaea, fungi, viruses, and bacteriophages, and, that overgrowth is often associated with changes in the quantitative part of various members of the microbiota. In addition, in 


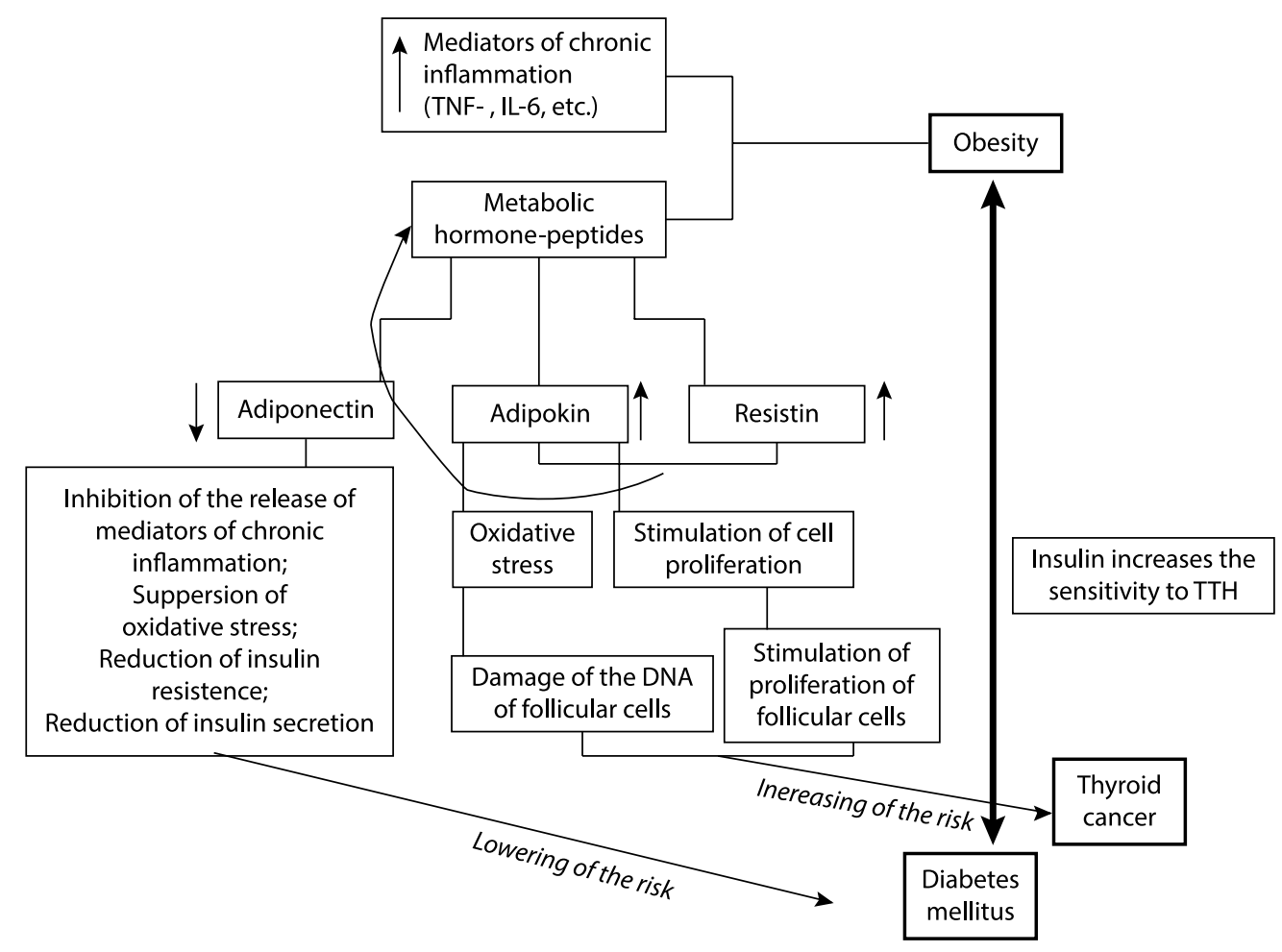

Figure. Pathologic mechanisms underlying the increase in the risk of the development of thyroid cancer

animals with MyD88 deficiency grown in conventional facilities, norovirus infection and reactivation of infectious endogenous retroviruses, such as mouse leukemia virus, are common and lead to altered innate and adaptive immune responses $[60,63]$.

Among the mechanisms to influence the microflora of the immune system, a significant role is occupied by short-chain fatty acids (SCFA), which prodused by bacteria's during fermentation, because it affects an mucosal immunity via signaling through the receptorassociated protein $\mathrm{G}$, i.e. SCFA induce production IL-18 enterocytes $[65,66]$, and also have a significant effect on T-lymphocytes, affecting their size and function [65-67].

Studies show that Bacteroides fragilis, normal human intestinal microbiota component, can control the differentiation of Treg-cells, that secreting IL-10 through its capsule polysaccharide-A, TLR2 agonist [59]. B. fragilis has also been shown to protect mice from a viral infection - Helicobacter hepaticus and trinitrobenzene sulfonic acid (TNBS) that induce colitis $[59,68]$.

Among the species with the ability to increase the immune response of the intestinal mucosa is segmented filamentous bacteria (SFB) - a type of bacteria that is present in the ileum of mice. They stimulate postpartum maturation of the immune response with lysis in the intestine of mice [69]. In the absence of SFB in mice, it was shown that they have lower titers of $\lg A$, low mucosal Th1 and Th17 cells quantity and have a poor response to intestinal pathogens such as Citrobacter rodentium and Salmonella spp. This fact allows us assuming that barrier function is supported by an immunological response caused by a microbiota [70-72].

Thus, obesity is one of the factors for the possible development of oncological processes in the body due to hormonal imbalance and the development of chronic inflammation, which stimulate mitogenic cell division. In particular, adipose tissue hormones such as leptin, adiponectin stimulates the proliferation of follicular cells, directly increases the likelihood of developing thyroid cancer.

Although research has shown a weak link between diabetes and thyroid cancer in women and a much weaker link in men, the fact that treatment aimed at increasing own insulin or using its analogues has a direct correlation connection with the development of cancer through the stimulation of receptors that induce proliferation. At the same time, treatment of DM with metformin and/or acarbose, in contrast, induced remission in cancer patients according to studies. 
Therefore, obesity, and often associated DM and intestinal microbiota disorders, may increase the risk of cancer, particularly papillary thyroid cancer.

Authors declare that there is no conflict of interest.

\section{LITERATURE/REFERENCES}

1. World Health Organization. Global report on diabetes. Geneva: World Health Organization, 2016.

2. Abelson P, Kennedy D. The Obesity Epidemic. AAAS, 2004;304:1413. DOI: 10.1126/science.304.5676.1413.

3. Goljan EF. Rapid Review Pathology, 4th edition. 2013;623-24.

4. Coughlin SS, Calle EE, Teras LR, Petrelli J, Thun MJ. Diabetes mellitus as a predictor of cancer mortality in a large cohort of US adults. Am J Epidemiol. 2004;159 (12):1160-7. DOI: 10.1093/aje/kwh161.

5. Davies L, Welch HG. Increasing incidence of thyroid cancer in the United States, 1973-2002. JAMA. 2006;295 (18):2164-7. DOI: 10.1001/jama.295.18.2164.

6. Meinhold CL, Ron E, Schonfeld SJ et al. Nonradiation risk factors for thyroid cancer in the US radiologic technologists' study. Am J Epidemiol. 2010;171(2):24252. DOI: 10.1093/aje/kwp354.

7. Wu P. Thyroid disorders and diabetes. It is common for a person to be affected by both thyroid disease and diabetes. Diabetes Self-Management. 2007;24(5):80-87.

8. Aschebrook-Kilfoy B, Sabra MM, Brenner A. et al. Diabetes and thyroid cancer risk in the National Institutes of Health-AARP Diet and Health study. Thyroid. 2011;21(9): 957-63. DOI: $10.1089 /$ thy.2010.0396.

9. Gursoy A. Rising thyroid cancer incidence in the world might be related to insulin resistance. Medical Hypotheses. 2010;74(1):35-6. DOI: 10.1016/j.mehy.2009.08.021.

10. Tramontano D, Cushing GW, Moses AC, Ingbar SH. Insulin-like growth factor-I stimulates the growth of rat thyroid cells in culture and synergized the stimulation of DNA synthesis induced by TSH and Graves'-lgG. Endocrinology. 1986;119(2):940-2. DOI: $10.1155 / 2012 / 578285$.

11. Rezzonico JN, Rezzonico M, Pusiol E, Pitoia F, Niepomniszcze $\mathrm{H}$. Increased prevalence of insulin resistance in patients with differentiated thyroid carcinoma. Metabolic Syndrome and Related Disorders. 2009; 7(4):375-80. DOI: 10.1089/met.2008.0062.

12. Renehan AG, Tyson M, Egger M, Heller RF, Zwahlen $M$. Body-mass index and incidence of cancer: a systematic review and meta-analysis of prospective observational studies. The Lancet. 2008;371(9612):569-78. DOI: 10.1016/S0140-6736(08)60269-X.
13. Kitahara CM, Platz EA, Freeman LE et al. Obesity and thyroid cancer risk among US men and women: a pooled analysis of five prospective studies. Cancer Epidemiology Biomarkers and Prevention. 2011;20(3):464-72. DOI: 10.1158/1055-9965.EPI-10-1220.

14. Smith U, Gale EA. Does diabetes therapy influence the risk of cancer? Diabetologia. 2009;52(9):1699-708. DOI: 10.1007/s00125-009-1441-5.

15. Bowker SL, Majumdar SR, Veugelers $P$, Johnson JA. Increased cancer-related mortality for patients with type 2 diabetes who use sulfonylureas or insulin. Diabetes Care. 2006;29(2):254-8. DOI: 10.2337/ diacare.29.02.06.dc05-1558.

16. Yang YX, Hennessy S, Lewis JD. Insulin therapy and colorectal cancer risk among type 2 diabetes mellitus patients. Gastroenterology. 2004;127(4):1044-50. DOI: 10.1053/j.gastro.2004.07.011.

17. Cowey S, Hardy RW. The metabolic syndrome: a highrisk state for cancer? Am J of Pathol. 2006;169(5):150522. DOI: 10.2353/ajpath.2006.051090.

18. Borena W, Stocks T, Jonsson H et al. Serum triglycerides and cancer risk in the metabolic syndrome and cancer (MeCan) collaborative study. Cancer Causes Control. 2011;22(2):291-9.

19. Almquist $M$, Johansen $D$, Bjorge T et al. Metabolic factors and risk of thyroid cancer in the metabolic syndrome and cancer project (Me-Can). Cancer Causes Control. 2011;22(5):743-51. DOI: 10.1007/s10552-011-9747-2.

20. Giovannucci E. Vitamin D status and cancer incidence and mortality. Adv Exp Med Biol. 2008;624:31-42. DOI: 10.3109/07357909509024919.

21.Tamez-Perez HE, Martinez E, Quintanilla-Flores DL, Tamez-Pena AL et al. The rate of primary hypothyroidism in diabetic patients is greater than in the non-diabetic population. An observational study. Med Clin. 2012;138(11):475-7. DOI: 10.1016/j.medcli.2011.08.009.

22. Kitahara CM, Platz EA, Beane Freeman LE et al. Physical activity, diabetes, and thyroid cancer risk: a pooled analysis of five prospective studies. Cancer Causes Control. 2012;23(3):463-71. DOI: 10.1007/s10552-0129896-y.

23. Yeo Y, Ma SH, Hwang Y et al. Diabetes mellitus and risk of thyroid cancer: a meta-analysis. PloS One. 2014;9(6). DOI: 10.1371/journal.pone.0098135.

24. Luo J, Phillips L, Liu S, Wactawski-Wende J, Margolis KL. Diabetes, diabetes treatment, and risk of thyroid cancer. J Clin Endocrinol. 2016;101(3):1243-8. DOI: 10.1210/ jc.2015-3901.

25. Li C, Kuang J, Zhao Y et al. Effect of type 2 diabetes and antihyperglycemic drug therapy on signs of tumor 
invasion in papillary thyroid cancer. Endocrine. 2020;69(1):92-9. DOI: 10.1016/j.phrs.2016.10.006.

26. Novosyadlyy R, Lann DE, Vijayakumar A et al. Insulinmediated acceleration of breast cancer development and progression in a nonobese model of type 2 diabetes. Cancer Res. 2010;70(2):741-51. doi: 10.1158/0008-5472. CAN-09-2141.

27. Romero IL, McCormick A, McEwen KA et al. Relationship of type 2 diabetes and metformin use to ovarian cancer progression, survival, and chemosensitivity. Obstet Gynecol. 2012; 119: 61-7. DOI: 10.1097/ AOG.0b013e3182393ab3.

28. Jang EK, Kim WG, Kwon $\mathrm{H}$ et al. Metformin is associated with a favorable outcome in diabetic patients with cervical lymph node metastasis of differentiated thyroid cancer. Eur Thyroid J. 2015;4:181-8. DOI: 10.1159/000437365.

29. Xu L, Port M, Landi S et al. Obesity and the risk of papillary thyroid cancer: a pooled analysis of three case - control studies. Thyroid J. 2014;24(6):966-74. DOI: 10.1089/ thy.2013.0566.

30. Park S, Willingham MC, Qi J, Cheng SY. Metformin and JQ1 synergistically inhibit obesity-activated thyroid cancer. Endocr Relat Cancer. 2018;25(10):865-77. DOI: 10.1530/ERC-18-0071.

31. Cho YY, Kang MJ, Kim SK et al. Protective effect of metformin against thyroid cancer development: a population-based study in Korea. Thyroid. 2018;28(7):864-70. doi:10.1089/thy.2017.0550.

32. World Health Organization. Obesity and Overweight Fact Sheet. Geneva, Switzerland: World Health Organization; 2018 Jul 1.

33. NCD Risk Factor Collaboration (NCD-RisC). Worldwide trends in body - mass index, underweight, overweight, and obesity from 1975 to 2016: a pooled analysis of 2416 population - based measurement studies in 128.9 million children, adolescents, and adults. Lancet. 2017; 390: 2627-42.DOI: 10.1016/S0140-6736(17)32129-3.

34. Stuttard J, Zhou B, Kontis V et al. Worldwide burden of cancer attributable to diabetes and high body - mass index: a comparative risk assessment. Lancet Diabetes Endocrinol. 2018;6:e6-e15. DOI: 10.1016/S22138587(17)30366-2.

35. Bandera EV, Fay SH, Giovannucci E et al. The use and interpretation of anthropometric measures in cancer epidemiology: a perspective from the World Cancer Research Fund International Continuous Update Project. Int J Cancer. 2016; 139: 2391-7. DOI: 10.1002/ijc.30248.

36. de Onis M, Onyango AW, Borghi E et al. Development of a WHO growth reference for school-aged children and adolescents. Bull World Health Organ. 2007; 85: 660-7. DOI: 10.2471/blt.07.043497.

37. Song Y, Wang HJ, Dong B et al. 25-year trends in gender disparity for obesity and overweight by using $\mathrm{WHO}$ and IOTF definitions among Chinese school - aged children: a multiple cross - sectional study [serial online]. BMJ Open. 2016;6:e011904. DOI: 10.1136/ bmjopen-2016-011904.

38. Rito A, Wijnhoven TM, Rutter $\mathrm{H}$ et al. Prevalence of obesity among Portuguese children (6-8 years old) using three definition criteria: COSI Portugal, 2008. Pediatr Obes. $2012 ; 7: 413-22$. DOI: 10.1111/j.2047-6310.2012.00068.x.

39. Keum N, Song M, Giovannucci ED, Eliassen AH. Obesity and body composition. In: M Thun, MS Linet, JR Cerhan, CA Haiman, D Shottenfeld, eds. Cancer Epidemiology and Prevention. Chapter 20. 4th ed. New York: Oxford University Press;2017:351-76.DOI: 10.3322/caac.21499.

40. Bulun SE, Chen D, Moy I, Brooks DC, Zhao H. Aromatase, breast cancer and obesity: a complex interaction. Trends Endocrinol Metab. 2012;23:83-9. DOI: 10.1016/j. tem.2011.10.003.

41. Key TJ, Appleby PN, Reeves GK et al. Body mass index, serum sex hormones, and breast cancer risk in postmenopausal women. J Natl Cancer Inst. 2003;95:1218-26. DOI: 10.1093/jnci/djg022.

42. Allott EH, Masko EM, Freedland SJ. Obesity and prostate cancer: weighing the evidence. Eur Urol. 2013; 63: 8009. DOI: 10.1016/j.eururo.2012.11.013.

43. Williams G. Aromatase up-regulation, insulin and raised intracellular estrogens in men, induce adiposity, metabolic syndrome and prostate disease, via aberrant ER-alpha and GPER signaling. Mol Cell Endocrinol. 2012;351:269-78. DOI: 10.1016/j.mce.2011.12.017.

44. Freedland SJ, Platz EA. Obesity and prostate cancer: making sense out of apparently conflicting data. Epidemiol Rev. 2007;29:88-97. DOI: 10.1093/epirev/mxm006.

45. Platz EA, Leitzmann MF, Rifai $\mathrm{N}$ et al. Sex steroid hormones and the androgen receptor gene CAG repeat and subsequent risk of prostate cancer in the prostatespecific antigen era. Cancer Epidemiol Biomarkers Prev. 2005; 14: 1262-9. DOI: 10.1158/1055-9965.EPI-04-0371.

46. Severi G, Morris HA, Maclnnis RJ et al. Circulating steroid hormones and the risk of prostate cancer. Cancer Epidemiol Biomarkers Prev. 2006;15:86-91. DOI: 10.1158/1055-9965.EPI-05-0633.

47. Hursting SD, Digiovanni J, Dannenberg AJ et al. Obesity, energy balance, and cancer: new opportunities for prevention. Cancer Prev Res (Phila). 2012;5:1260-72. DOI: 10.1158/1940-6207.CAPR-12-0140. 
48. Lee $\mathrm{CH}$, Woo YC, Wang $\mathrm{Y}$ et al. Obesity, adipokines and cancer: an update. Clin Endocrinol (Oxf). 2015; 83: 147-56. DOI: 10.1111/cen.12667.

49. Dalamaga M, Diakopoulos KN, Mantzoros CS. The role of adiponectin in cancer: a review of current evidence. Endocr Rev. 2012;33:547-594. DOI: 10.1210/er.20111015.

50. Liu LY, Wang M, Ma ZB et al. The role of adiponectin in breast cancer: a meta - analysis [serial online]. PLoS One. 2013;8:e73183. DOI: 10.1371/journal.pone.0073183.

51. Katira A, Tan PH. Evolving role of adiponectin in cancer - controversies and update. Cancer Biol Med. 2016;13:101-19. DOI: 10.28092/j.issn.20953941.2015.0092.

52. Liao LM, Weinstein SJ, Pollak M et al. Prediagnostic circulating adipokine concentrations and risk of renal cell carcinoma in male smokers. Carcinogenesis. 2013;34:109-12. DOI: 10.1093/carcin/bgs322.

53. Milic S, Lulic D, Stimac D. Non-alcoholic fatty liver disease and obesity: biochemical, metabolic and clinical presentations. World J Gastroenterol. 2014;20:9330-7. DOI: 10.3748/wjg.v20.i28.9330.

54. Jacobson BC, Somers SC, Fuchs CS, Kelly CP, Camargo CA Jr. Body mass index and symptoms of gastroesophageal reflux in women. $\mathrm{N}$ Engl J Med. 2006;354:2340- 8. DOI: 10.1056/NEJMoa054391.

55. Spechler SJ. Barrett esophagus and risk of esophageal cancer: a clinical review. JAMA. 2013;310: 627-36. DOI: 10.1001/jama.2013.226450.

56. Maclure KM, Hayes KC, Colditz GA et al. Weight, diet, and the risk of symptomatic gallstones in middle-aged women. N Engl J Med. 1989;321:563-9. DOI: 10.1056/ NEJM198908313210902.

57. Espinoza JA, Bizama C, Garcia P et al. The inflammatory inception of gallbladder cancer. Biochim Biophys Acta. 2016;1865:245-54. DOI: 10.1016/j.bbcan.2016.03.004.

58. Belkaid Y, Hand TW. Role of the microbiota in immunity and inflammation. Cell. 2014;157:121-41. DOI: 10.1016/j. cell.2014.03.011.

59. Round JL, Mazmanian SK. Inducible Foxp3 + regulatory T-cell development by a commensal bacterium of the intestinal microbiota. Proc. Natl. Acad. Sci. USA. 2010;107:12204-9. DOI: 10.1073/pnas.0909122107.

60. Larsson E, Tremaroli V, Lee YS et al. Analysis of gut microbial regulation of host gene expression along the length of the gut and regulation of gut microbial ecology through MyD88. Gut. 2012;61:1124-31. DOI: 10.1136/gutjnl-2011-301104.

61. Vaishnava S, Behrendt CL, Ismail AS, Eckmann L, Hooper LV. Paneth cells directly sense gut commensals and maintain homeostasis at the intestinal host-microbial interface. Proc. Natl. Acad. Sci. USA. 2008;105:20858-63. DOI: $10.1073 /$ pnas.0808723105.

62. Kim YG, Udayanga KG, Totsuka N et al. Gut dysbiosis promotes $\mathrm{M} 2$ macrophage polarization and allergic airway inflammation via fungi-induced PGE (2). Cell Host Microbe. 2014;15:95-102. DOI: 10.1016/j. chom.2013.12.010.

63. Young GR, Exmond U, Salcedo $R$ et al. Resurrection of endogenous retroviruses in mice antibody deficient. Nature. 2012;491:774-8. DOI: 10.1038/nature11599.

64. Mangeney M, Pothlichet J, Renard M, Ducos B, Heidmann T. Endogenous retrovirus expression is required for murine melanoma tumor growth in vivo. Cancer Res. 2005;65:2588-91. DOI: 10.1158/0008-5472.CAN-04-4231.

65. Singh N, Gurav A, Sivaprakasam S et al. Activation of Gpr109a, receptor for niacin and the commensal metabolites butyrate, suppresses colonic inflammation and carcinogenesis. Immunity. 2014;40:128-39. DOI: 10.1016/j.immuni.2013.12.007.

66. Kalina U, Koyama N, Hosoda T et al. Enhanced production of IL-18 in butyrate-treated intestinal epithelium by stimulation of the proximal promoter region. Eur. J. Immunol. 2002;32:2635-43. DOI: 10.1002/1521-4141(200209)32:9<2635::AIDIMMU2635>3.0.CO;2-N.

67. Smith PM, Howitt MR, Panikov N et al. The microbial metabolites, shortchain fatty acids, regulate colonic Treg cell homeostasis. Science. 2013;341:569-73. DOI: 10.1016/j.immuni.2018.10.013.

68. Mazmanian SK, Round JL, Kasper DL. A microbial symbiosis factor prevents intestinal inflammatory disease. Nature. 2008;453:620-5. DOI: 10.1038/ nature07008.

69. Talham GL, Jiang HQ, Bos NA, Cebra JJ. Segmented filamentous bacteria are potent stimuli of a physiologically normal state of the murine gut mucosal immune system. Infect. Immun. 1999;67:1992-2000.

70. Gaboriau-Routhiau V, Rakotobe $S$ et al. The key role of segmented filamentous bacteria in the coordinated maturation of gut helper T cell responses. Immunity. 2009;31:677-89. DOI: 10.1016/j.immuni.2009.08.020.

71. Ivanov II, Atarashi K, Manel N, Brodie EL, Shima T. Induction of intestinal Th17 cells by segmented filamentous bacteria. Cell. 2009;139:485-98. DOI: 10.1016/j.cell.2009.09.033.

72. Garland CD, Lee A, Dickson MR. Segmented filamentous bacteria in the rodent small intestine: their colonization of growing animals and possible role in host resistance to Salmonella. Microb. Ecol. 1982;8:181-90. 


\section{SUMMARY}

Risk factors for papillary thyroid cancer in obesity and diabetes mellitus

\section{S. G. Gychka ', B. Ya. Serbin ', S. I. Nikolaenko ', M. A. Matviian 1, S. Sujima 2, O. A. Tovkai ${ }^{3}$ \\ ${ }^{1}$ Bogomolets National Medical University, Kyiv \\ ${ }^{2}$ Kyiv Medical University \\ ${ }^{3}$ Ukrainian Scientific and Practical Center for Endocrine Surgery, Transplantation of Endocrine Organs and Tissues of the Ministry of Health of Ukraine, Kyiv}

Abstract. Obesity and resulting diabetes mellitus are being two of the most prevalent pathological conditions worldwide accounting almost 2 billion adults and 340 million children affected. In the same time, global cancer statistics rises each year showing the growth in the number of cases of papillary thyroid cancer. Relationship between thesediseases has created strong interest among scientists and discovered new directions in prevention and therapy. Moreover, obesity usually leads to the disturbance in gut microbiota. Accordingly, the aim of our research was to summarize the evidence of the impact of these risk factors on the possible development of papillary thyroid cancer.

Current article reflects newest achievements in the understanding of pathological mechanisms underlying the epidemiological trends connecting adiposity, hyperglycemia, diabetes mellitus, antidiabetic therapy and microbiota changes.

Wide range of evidences testify in favor that obesity is one of the factors for the possible development of oncological processes in the body due to hormonal imbalance and the development of chronic inflammation, which stimulate mitogenic cell division. Complete chronicinflammation, often found in obese people, predisposesto a particular type of cancer, creating a tissueenvironment that creates oxidative stress, stimulatesDNA damage, increases cell proliferation, and inhibitsapoptosis.Talking about diabetes mellitus, recent studies suggested that when culturing follicular cells, their quantity increases significantly in the presence of insulin and TSH as compared to thepresence of only TSH. This phenomenon occurs due insulinstructural similarity to insulin-like growth factor 1 . Same mechanism is also related to increase in thyroid cancer risk in diabetic patients prescribed with sulfonylurea and injectable insulins.

Other points are still partly unclear and need further investigations and therapeutic implications.
Key words: thyroid gland, papillary thyroid cancer, obesity, diabetes mellitus, risk factors.

\section{PEЗЮME}

Фактори ризику папілярного раку щитоподібної залози при ожирінні та цукровому діабеті

\section{С. Г. Гичка ', Б. Я. Сербін ', С. І. Ніколаєнко',} М. А. Матвіян ${ }^{1}$, С. Судзіма ${ }^{2}$, О. А. Товкай ${ }^{3}$

${ }^{1}$ Національний медичний університет імені О. О. Богомольчя, Київ

${ }^{2}$ Київський медичний університет

${ }^{3}$ Український науково-практичний чентр ендокринної хірургії, трансплантації ендокринних органів і тканин МОЗ України, Київ

Ожиріння і, як наслідок цукровий діабет, є двома захворюваннями з групи найпоширеніших патологічних станів у світі, що вразили вже майже 2 млрд дорослих та 340 млн дітей. Водночас міжнародна канцер-статистика щороку зростає, у тому числі збільшується кількість випадків папілярного раку щитоподібної залози. Взаємозв'язок між цими захворюваннями породжує сильний інтерес серед науковців, а його розуміння відкриває нові напрямки у профілактиці та терапії цих захворювань. Більше того, ожиріння зазвичай призводить до порушення мікробіому кишечника. Відповідно, метою нашого дослідження було узагальнити результати досліджень, присвячених впливу цих чинників на можливий розвиток папілярного раку щитоподібної залози.

Дана стаття відображає новітні досягнення у розумінні патологічних механізмів, що лежать в основі епідеміологічних тенденцій, які пов'язують ожиріння, гіперглікемію, цукровий діабет, протидіабетичну терапію та зміни мікробіому.

Широкий спектр фактів свідчить на користь того, що ожиріння $\epsilon$ одним із чинників можливого розвитку онкологічних процесів в організмі через гормональний дисбаланс та розвиток хронічного запалення, що стимулює мітогенний поділ клітин. Тривале хронічне запалення, яке часто зустрічається у людей із ожирінням, призводить до підвищеного ризику розвитку певних типів раку, створюючи тканинне середовище з підвищеним оксидантним стресом, що, у свою чергу, стимулює пошкодження ДНК, пришвидшує проліферацію клітин і гальмує апоптоз. Щодо цукрового діабету, то останні дослідження продемонстрували, що при культивуванні фолікулярних клітин їх кількість значно зростає в присутності інсуліну та ТТГ порівняно з наявністю лише ТТГ. Це явище відбувається через структурну схожість 
інсуліну до інсуліноподібного фактора 1. Цей же механізм також пов'язаний із збільшенням ризику раку щитоподібної залози у хворих на цукровий діабет, яким призначають сульфонілсечовину та ін'єкційні інсуліни.

Інші аспекти досі лишаються частково незрозумілими і потребують подальших досліджень для зміни терапевтичних підходів до профілактики і лікування.

Ключові слова: щитоподібна залоза, папілярний рак щитоподібної залози, ожиріння, цукровий діабет, фактори ризику.

\section{PEЗЮME}

Факторы риска папиллярного рака щитовидной железы при ожирении и сахарном диабете

С. Г. Гичка ', Б. Я. Сербин ${ }^{1,}$ С. И. Николаенко ', М. А. Матвиян ${ }^{1}$, С. Судзима ${ }^{2}$, О. А. Товкай ${ }^{3}$

\author{
${ }^{1}$ Национальный медицинский университет \\ имени А.А. Богомольча, Киев \\ ${ }^{2}$ Киевский медицинский университет, Киев \\ ${ }^{3}$ Украинский научно-практический чентр эндокринной \\ хирургии, трансплантации эндокринных органов \\ и тканей МЗ Украины, Киев
}

Ожирение и, как следствие сахарный диабет, являются двумя заболеваниями из группы самых распространенных патологических состояний в мире, поразили уже почти 2 млрд взрослых и 340 млн детей. В то же время международная канцер-статистика ежегодно растет, в том числе увеличивается количество случаев папиллярного рака щитовидной железы. Взаимосвязь между этими заболеваниями порождает сильный интерес среди ученых, но его понимание открывает новые направления в профилактике и терапии этих заболеваний. Более того, ожирение обычно приводит к нарушению микробиом кишечника. Соответственно, целью нашего исследования было обобщить результаты исследований, посвященных влиянию этих факторов на возможное развитие папиллярного рака щитовидной железы.

Данная статья отражает новейшие достижения в понимании патологических механизмов, лежащих в основе эпидемиологических тенденций, которые связывают ожирение, гипергликемию, сахарный диабет, противодиабетическую терапию и изменения микробиома.

Широкий спектр доказательств свидетельствует в пользу того, что ожирение является одним из факторов возможного развития онкологических процессов в организме из-за гормонального дисбаланса и развития хронического воспаления, стимулирует митогенное деление клеток. Длительное хроническое воспаление, которое часто встречается у людей с ожирением, приводит к повышенному риску развития определенных типов рака, создавая тканевую среду с повышенным оксидантным стрессом, что, в свою очередь, стимулирует повреждения ДНК, ускоряет пролиферацию клеток и тормозит апоптоз. Относительно сахарного диабета, последние исследования показали, что при культивировании фолликулярных клеток их количество значительно возрастает в присутствии инсулина и ТТГ по сравнению с наличием только ТТГ. Это явление происходит из-за структурного сходства инсулина с инсулиноподобным фактором 1. Этот же механизм также связан с повышением риска рака щитовидной железы у больных с сахарным диабетом, которым назначают сульфонилмочевину и инъекционные инсулины.

Другие аспекты до сих пор остаются частично непонятными и требуют дальнейших исследований для изменения терапевтических подходов к профилактике и лечению.

Ключевые слова: щитовидная железа, рак щитовидной железы, ожирение, сахарный диабет, факторы риска.

Дата надходження до редакції 04.08.2020 p. 